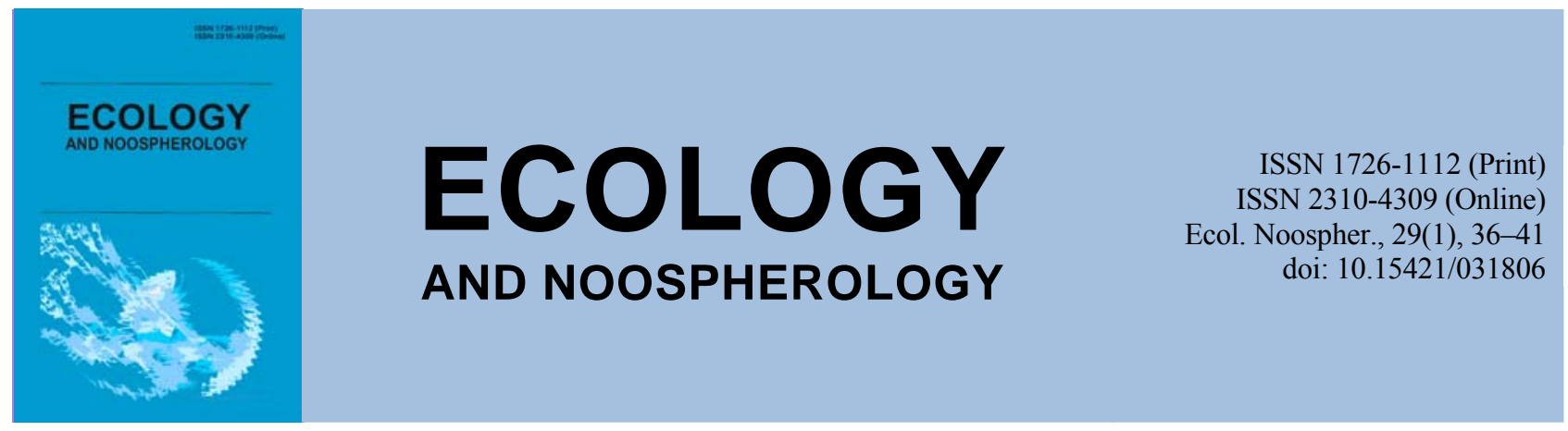

\title{
Condition, protection and maintenance of age-old pedunculate oak trees in Feofania forest
}

\author{
Yu. S. Prokopuk, Ya. I. Krylov \\ Institute for Evolutionary Ecology of the National Academy \\ of Sciences of Ukraine, Kyiv, Ukraine
}

Article info

Received 27.05.2018

Received in revised form 06.06 .2018

Accepted 12.06.2018

Institute for Evolutionary Ecology of the National Academy of Sciences of Ukraine,

Lebedeva str., 37, Kyiv,

03143, Ukraine.

Tel.: +38-097-760-25-39

E-mail:

ju.prokopuk91@gmail.com
Prokopuk, Yu. S., \& Krylov, Ya. I. (2018). Condition, protection and maintenance of age-old pedunculate oak trees in Feofania forest. Ecology and Noospherology, 29(1), 36-41. doi:10.15421/031806

Large old trees are significant elements of forests, arboretums, botanical gardens and parks and perform a number of unique functions contributing to ecosystem integrity and biodiversity. At the same time human activities such as compaction of topsoil layers, deterioration of soil permeability and soil aeration drive the decline of large old trees. The human impact is also exacerbated by plants inevitable physiological age-specific changes. The presence of such old trees in urban environments brings great scientific promises enhancing a social, cultural and historical forest value, although these benefits increase responsibility for trees maintaining. Regarding old-growth trees historical, cultural, and environmental significance and their overall vulnerability, the individual-by-individual tree protection measures are required. Pedunculate oak (Quercus robur L.) is among the most widespread long-lived species in Europe, in particular in Ukraine. In Feofania (or Theophania) forest, that is an oak-hornbeam forest located in southern part in Kyiv, the age of the oldest oak trees reaches about 300 years. In this article, we aim to estimate vitality, overall condition, and recreational digression stages of pedunculate oak trees and to develop the recommendations to maintain and extend trees longevity in Feofania forest. We estimate the stages of recreational digression and vitality using an approach of Hensiruk et al. (1987) and Sanitary Regulations in forests of Ukraine (1995) respectively. The dendrochronological analysis is performed on core samples from sixteen age-old pedunculate oaks in order to determine their exact cambial age and to evaluate their growth rates. We use at least two cores per tree extracted at a height from $0.5 \mathrm{~m}$ to $1.3 \mathrm{~m}$ above ground level with an increment borer. The tree-ring widths are measured using AxioVision (Carl Zeiss) software to the nearest $0.01 \mathrm{~mm}$. To identify false rings we employ stereomicroscope MBS-1. The individual tree-ring series are cross-dated, standardized and checked using the COFECHA program. Then we determine exact cambial age of oak trees as number of tree-rings in individual series. To estimate the age of trees with cores without pith we use a graphical method. The analyze is performed on 42 increment cores containing 7335 annual rings formed in the period from 1746 to 2016. Measured diameter of the age-old oaks ranges from $57.6 \mathrm{~cm}$ to $165.2 \mathrm{~cm}$. The longest chronological series contains 271 years. The age of studied trees varies from 202 to 275 years averaging 175 years and radial growth ranges from $1.07 \pm 0.400 \mathrm{~mm}$ to $2.85 \pm 1.487 \mathrm{~mm}$ averaging $1.95 \pm 0.792 \mathrm{~mm}$. In recent years the reduction of radial growth isn't observed, although in a long time interval in five studied trees the rings width not exceeds the individual series average value. However, the growth rate reducing could not be regarded as critical for trees vitality because it is above $10 \%$ of the average value yet. The evaluated mean increment coefficient is $5.13 \pm 1.482$ years in $\mathrm{cm}$ that allows to estimate the age of dominant and codominant oaks in the association of Galeobdoloni luteae-Carpinetum in other forests. The estimated vitality is mostly of 6-7 points. Five oaks are in «satisfactory condition», nine oaks are «weakened», one oak is «very weakened» and one tree is «dying». «Weakened» trees are with mechanically damaged stem and are often suffered from leaves defoliation caused by Acrocercops brongniardella and Microsphaera alphitoides. Regarding wood samples maintenance, the «dying» oak stem is found rotted in its center. The recreational digression is at the stage $1-4$. For eight oaks it is at the first stage, for four oaks at the second stage, for two oaks at the third stage and for two oaks at the fourth stage with $60 \%$ destruction of the understorey. The number of age-old $Q$. robur trees is limited, thus measures to care could consider individual tree-specific features. Given trees vitality and stages of recreational digression, we develop the guidelines to preserve and extend trees longevity. We also propose to include four old-growth oaks in the list of monumental plants. 


\title{
Стан, охорона та збереження багатовікових дерев дуба звичайного в урочищі «Феофанія»
}

\author{
Ю. С. Прокопук, Я. І. Крилов \\ Інститут еволюиійної екологї НАН України, Київ, Україна
}

Великі старі дерева є основними елементами лісових насаджень, дендропарків, ботанічних садів, парків та скверів. Виконуючи ряд унікальних функцій, на які неспроможні молоді дерева, вони відіграють ключову роль для збереження цілісності екосистем та біорізноманіття. Тому охорона старих дерев має важливе не тільки історико-культурне, а й екологічне значення. У цій роботі оцінено життєздатність, санітарний стан та стадії рекреаційної дигресії дерев дуба звичайного віком 202-275 років в урочищі «Феофанія», м. Київ. Радіальний приріст досліджених дерев варіює в межах від $1,07 \pm 0,400$ мм до $2,85 \pm 1,487$ мм та в середньому становить $1,95 \pm 0,792$ мм. Середній коефіцієнт радіального приросту для багатовікових дерев складає $5,13 \pm 1,428$ років/см. Запропоновано заходи для збереження та продовження віку дерев, чотирьом з яких рекомендовано надати статус пам’ятки природи місцевого значення.

Ключові слова: Quercus robur; хронологія; життєздатність; коефіцієнти приросту

Вступ

В Україні охороняється близько 2600 вікових, меморіальних та унікальних дерев, 3 них у м. Києві зростає більше 250 дерев, у Львівській і Тернопільській областях понад 200 у кожній, у Вінницькій, Черкаській, Хмельницькій та Чернігівській - по 160 дерев (Hrynnyk et al., 2010). Велику увагу у вивченні та збереженні багатовікових дерев приділено у працях Lypa O. L. (1958, 1967); Rubtsov L. I. (1959); Boreyko V. E. (2002); Popovych S. Yu. (2011); Shnayder S. L. et al. (2011); Kushnir A. I. et al. (2011); Onyshchenko V. A. (2015).

Дендрологічні парки разом із парками-пам'ятками садово-паркового мистецтва та ботанічними садами $\epsilon$ середовищем збереження та вивчення не тільки інтродукованих видів, а й багатовікових дерев. Більшість парків України закладено в кінці XVIII - першій половині XIX ст. на базі природних насаджень: «Олександрія» (1788р.), «Софіївка» (1796 р.), «Тростянець» (1834 р.), «Устимівський» (1893р.), тому вікові дерева складають значну частку їх дендрофлори та потребують відповідного індивідуального догляду та захисту (Klymenko et al., 1996; Halkin et al., 2013; Oleksiichenko, Podolkhova, 2016).

Згідно зі ст. 39 Лісового кодексу України (1994) багатовікові дерева виконують особливі природоохоронні, естетичні, наукові функції тощо. Останне зумовлено наступним: такі дерева $є$ унікальними об'єктами для вивчення довговічності деревних видів у різних типах насаджень, дослідження їхніх генетичних особливостей, наявності та характеру вікових змін приросту, визначення впливу клімату на приріст, реконструкції клімату минулих часів та датування археологічних знахідок. Екологічні функції старих дерев полягають у першу чергу у різнобічних зв'язках 3 великою кількістю інших організмів, вони є місцем оселення багатьох видів тварин, у тому числі таких, що занесені до Червоної книги України (Bilushenko, 2015).

Багатовікові дерева дуба звичайного (Quercus robur L.) стають привабливим об'єктом для туристів та відвідувачів парків, увагу яких привертають дерева-велетні 3 їх могутніми стовбурами, розлогою кроною та великим корінням. Поряд 3 цим зростає і рекреаційне навантаження на ці рослини, результатом чого $\epsilon$ витоптування та знищення живого покриву, ущільнення верхнього горизонту грунту, погіршення водопроникності грунту та аерації. Старі дерева зазвичай $\epsilon$ більш вразливими до таких чинників, тобто антропогенний вплив посилюється природними віковими змінами у фізіології рослин. При розробці заходів із збереження багатовікових дерев потрібно враховувати особливості місць зростання та оцінювати вразливість окремих дерев: санітарний стан, архітектоніку крони, наявність захворювань та ін. (Bengtsson, 2013).

Урочище «Феофанія» знаходиться на місці великого природного дубово-грабового лісу, який зростав тут принаймні до XVI століття (Netsvetov, Prokopuk, 2016). Цінність i унікальність дендрофлори урочища підтверджена його включенням до природно-заповідного фонду України та присвоєнням статусу «парку-пам'ятки садово-паркового мистецтва загальнодержавного значення». Тут проведено попередні роботи із збереження деревостанів - укладено електронну карту, виконано детальні дендрометричні вимірювання (Matiashuk et al., 2014). Використання методів дендрохронології та статистики дозволило припустити, що вік найстаріших дерев «Феофанії» сягає близько 300 років (Netsvetov, Prokopuk, 2016). Наявність дерев такого віку в міських умовах відкриває широкі наукові перспективи, збільшує соціально-культурну, історичну та освітню цінність насадження, разом з тим це підвищує відповідальність за їх збереження. Фактичне підтвердження гіпотези М.В.Нецветова та Ю. С. Прокопук (2016) щодо віку найстаріших дерев «Феофанії» можливе за умови абсолютного датування річних кілець повних кернів, тобто таких, що містять ядро. Укладання довгих хронологічних серій, на відміну від моделювання, більш повно розкриває науковий потенціал багатовікових дерев.

Метою цього дослідження було визначити точний камбіальний вік, укласти узагальнену хронологію ширини річного кільця, розрахувати коефіцієнти приросту, оцінити життєздатність, санітарний стан та рекреаційне навантаження, а також рекомендувати заходи щодо збереження та охорони багатовікових дерев дуба звичайного урочища «Феофанія».

\section{Матеріали та методи досліджень}

Попередньо було абсолютно датовано річні кільця 3 73 дерев дуба звичайного ( $Q$. robur $)$, з яких відібрано 163 довжиною хронологічної серії не менше як 200 років. Життєвий та санітарний стан дослідних дерев встановлювали in situ. У кожного дерева вимірювали висоту за допомогою висотоміра Анучина, визначали діаметр стовбура на висоті 1,3 м, фіксували географічні координати та визначали життєздатність за 8-бальною шкалою (Saveleva, 1975). Стадію рекреаційної дигресії оцінювали за Генсіруком (Hensiruk et al., 1987), а життєвий стан рослин - згідно 3 «Санітарними правилами у лісах України» (1995). Буравом Haglof на висоті від 0,5 до 1,3 м було відібрано не менше двох кернів із 16 вікових дерев. Для запобігання подальшого пошкодження дерев отвори замащували садовим варом. 
Для виключення помилки у встановленні віку дерев під час камеральних досліджень вимірювали ширину річних кілець за допомогою програми «AxioVision» (Carl Zeiss Microscopy $\mathrm{GmbH}$ ) 3 точністю до 0,01 мм та проводили перехресне датування у програмі «COFECHA» (Holmes, 1983). Наявність фальшивих кілець встановлювали під мікроскопом МБС-1. Для визначення віку дерев, керни яких не містять ядра через

\section{Таблиця 1}

Розташування, біометричні параметри, вік та життєздатність досліджених вікових дерев Quercus robur L. урочища «Феофанія»

\begin{tabular}{|c|c|c|c|c|c|c|c|c|c|}
\hline 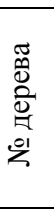 & 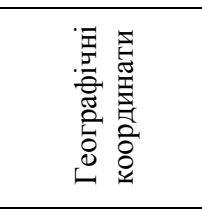 & 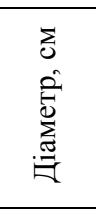 & 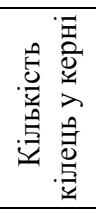 & 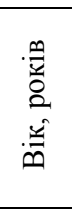 & 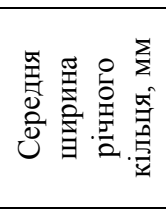 & 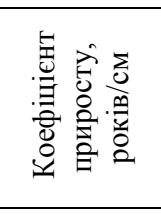 & 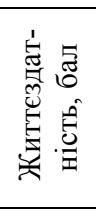 & 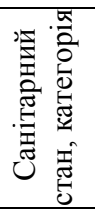 & 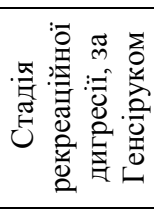 \\
\hline 1 & $\begin{array}{l}\text { N50 } 20,278^{\prime} \\
\text { E30 } 29,640^{\prime}\end{array}$ & 98,7 & 208 & 211 & $1,95 \pm 0,663$ & 5,14 & 6 & I & 3 \\
\hline 2 & $\begin{array}{l}\mathrm{N} 50^{\circ} 20,682^{\prime} \\
\mathrm{E} 30^{\circ} 29,529^{\prime}\end{array}$ & 108,9 & 204 & 211 & $2,43 \pm 0,819$ & 4,11 & 6 & I & 1 \\
\hline 3 & $\begin{array}{l}\mathrm{N} 50^{\circ} 20,898^{\prime} \\
\mathrm{E} 30^{\circ} 28,855^{\prime}\end{array}$ & 87,2 & 220 & 223 & $1,58 \pm 0,679$ & 6,33 & 7 & II & 2 \\
\hline 4 & $\begin{array}{l}\text { N50 } 20,204^{\prime} \\
\text { E30 } 29,574^{\prime}\end{array}$ & 86,5 & 212 & 215 & $1,56 \pm 0,581$ & 6,39 & 6 & II & 1 \\
\hline 5 & $\begin{array}{l}\text { N50 } 20,227^{\prime} \\
\mathrm{E} 30^{\circ} 29,603^{\prime}\end{array}$ & 80,2 & 210 & 216 & $1,66 \pm 0,930$ & 6,04 & 8 & I & 1 \\
\hline 6 & $\begin{array}{l}\text { N50 } 20,286^{\prime} \\
\text { E30 } 29,641^{\prime} \\
\end{array}$ & 57,6 & 209 & 213 & $1,07 \pm 0,400$ & 9,34 & 7 & II & 2 \\
\hline 7 & $\begin{array}{l}\text { N50 } 20,858^{\prime} \\
\text { E30 } 28,867^{\prime} \\
\end{array}$ & 106,0 & 214 & 218 & $1,67 \pm 0,828$ & 5,99 & 7 & II & 1 \\
\hline 8 & $\begin{array}{l}\text { N50 } 20,868^{\prime} \\
\text { E30 } 28,664^{\prime} \\
\end{array}$ & 108,2 & 202 & 207 & $2,19 \pm 0,709$ & 4,57 & 6 & II & 1 \\
\hline 9 & $\begin{array}{l}\mathrm{N} 50^{\circ} 20,623^{\prime} \\
\mathrm{E} 30^{\circ} 28,932^{\prime}\end{array}$ & 80,5 & 213 & 215 & $1,52 \pm 0,560$ & 6,56 & 7 & II & 1 \\
\hline 10 & $\begin{array}{l}\text { N50 } 20,720^{\prime} \\
\text { E30 } 29,424^{\prime}\end{array}$ & 163,9 & 247 & 256 & $1,78 \pm 0,787$ & 5,62 & 7 & II & 1 \\
\hline 11 & $\begin{array}{l}\text { N50 } 20,756^{\prime} \\
\text { E30 } 29,480^{\prime} \\
\end{array}$ & 165,2 & 271 & 275 & $1,81 \pm 0,651$ & 5,54 & 7 & III & 2 \\
\hline 12 & $\begin{array}{l}\mathrm{N} 50^{\circ} 20,945^{\prime} \\
\mathrm{E} 30^{\circ} 28,962^{\prime} \\
\end{array}$ & 131,6 & 199 & 202 & $2,45 \pm 1,147$ & 4,09 & 5 & II & 4 \\
\hline 13 & $\begin{array}{l}\text { N50 } 21,013^{\prime} \\
\text { E30 } 29,028^{\prime}\end{array}$ & 140,1 & 212 & 226 & $2,85 \pm 1,487$ & 3,51 & 3 & IV & 3 \\
\hline 14 & $\begin{array}{l}\text { N50 } 20,764^{\prime} \\
\text { E30 } 28,808^{\prime} \\
\end{array}$ & 117,8 & 212 & 216 & $2,35 \pm 0,538$ & 4,26 & 7 & I & 1 \\
\hline 15 & $\begin{array}{l}\text { N50 } 20,257^{\prime} \\
\text { E30 } 29,613^{\prime}\end{array}$ & 85,6 & 211 & 221 & $1,79 \pm 0,684$ & 5,60 & 7 & I & 4 \\
\hline 16 & $\begin{array}{l}\mathrm{N} 50^{\circ} 20,567^{\prime} \\
\mathrm{E} 30^{\circ} 29,625^{\prime} \\
\end{array}$ & 130,8 & 207 & 207 & $2,52 \pm 1,206$ & 3,96 & 7 & II & 2 \\
\hline \multicolumn{2}{|r|}{ Середнє } & & & & $1,95 \pm 0,792$ & $5,13 \pm 1,428$ & & & \\
\hline
\end{tabular}

Примітка. Вік наведено станом на 2016 рік.

ексцентричність приросту, використовували модифікований графічний метод (Rozas, 2003). У комп'ютерній графічній програмі обирали розмір кола, що накладався на крайню, найближчу до ядра дугу річного кільця керна. За відношенням довжини радіуса цього кола та середнім приростом п'яти суміжних річних кілець розраховували кількість кілець, яких не вистачає до серцевини. Сума розрахованих та датованих кілець становила вік дерева.

\section{Результати та їх обговорення}

Iз 16 вікових дерев дуба звичайного було відібрано 42 керни, що містили 7335 річних кілець, сформованих 3 1746 по 2016 роки. Мінімальний виміряний діаметр на висоті 1,3 м становив $57,6 \mathrm{~cm}$, а максимальний $-165,2 \mathrm{~cm}$ (табл. 1). Найдовша хронологічна серія, тобто кількість датованих кілець, становила 271 рік, а середня довжина серії-175 років (рис. 1). Середній річний радіальний приріст дерев $Q$. robur складав $1,95 \pm 0,792$ мм та варіював у

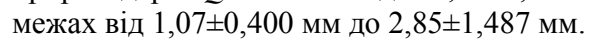

У більшості досліджених дерев зниження радіального приросту останніми роками не спостерігається. Однак у дерев № 1, 2, 4, 11, 12, 13, 15 ширина річних кілець досить тривалий час не перевищувала багаторічне середнє значення (рис. 1, табл. 1). Таке зменшення приросту не можна вважати критичним для життєздатності дерев, оскільки в жодного 3 них ширина річних кілець не знижувалась до $10 \%$ від середнього значення (Drobyshev et al., 2008).

У цілому середній радіальний приріст досліджених дубів урочища «Феофанія» близький до приросту дерев цього виду, що зростають в оптимальних умовах. У дерев в екстремальних умовах, а саме: за високої повторюваності посух, глибокого залягання грунтових вод, низьких температур у вегетаційний період радіальний приріст значно менший порівняно зі сприятливими умовами. Так, середній приріст багатовікових дерев дуба звичайного у Швеції, на північній межі їх природного ареалу, становив 1,26 мм (Drobyshev, Niklasson, 2010), а приріст вікових дерев Quercus robur Великої Британії, де цей вид знаходиться в оптимальних умовах, перебував у межах від 2,5 до 5 мм (White, 1998). Приріст вікових дубів у байраках 
степової зони України значно варіює в залежності від локальних умов. Так, у верхній третині схилів на вершинах пагорбів середній приріст складав
$1,47 \pm 0,31$ мм, а в нижній третині та в тальвегу $2,50 \pm 0,79$ мм (Netsvetov et al., 2017). Ще менше значення середнього приросту було зафіксовано в 250-річних

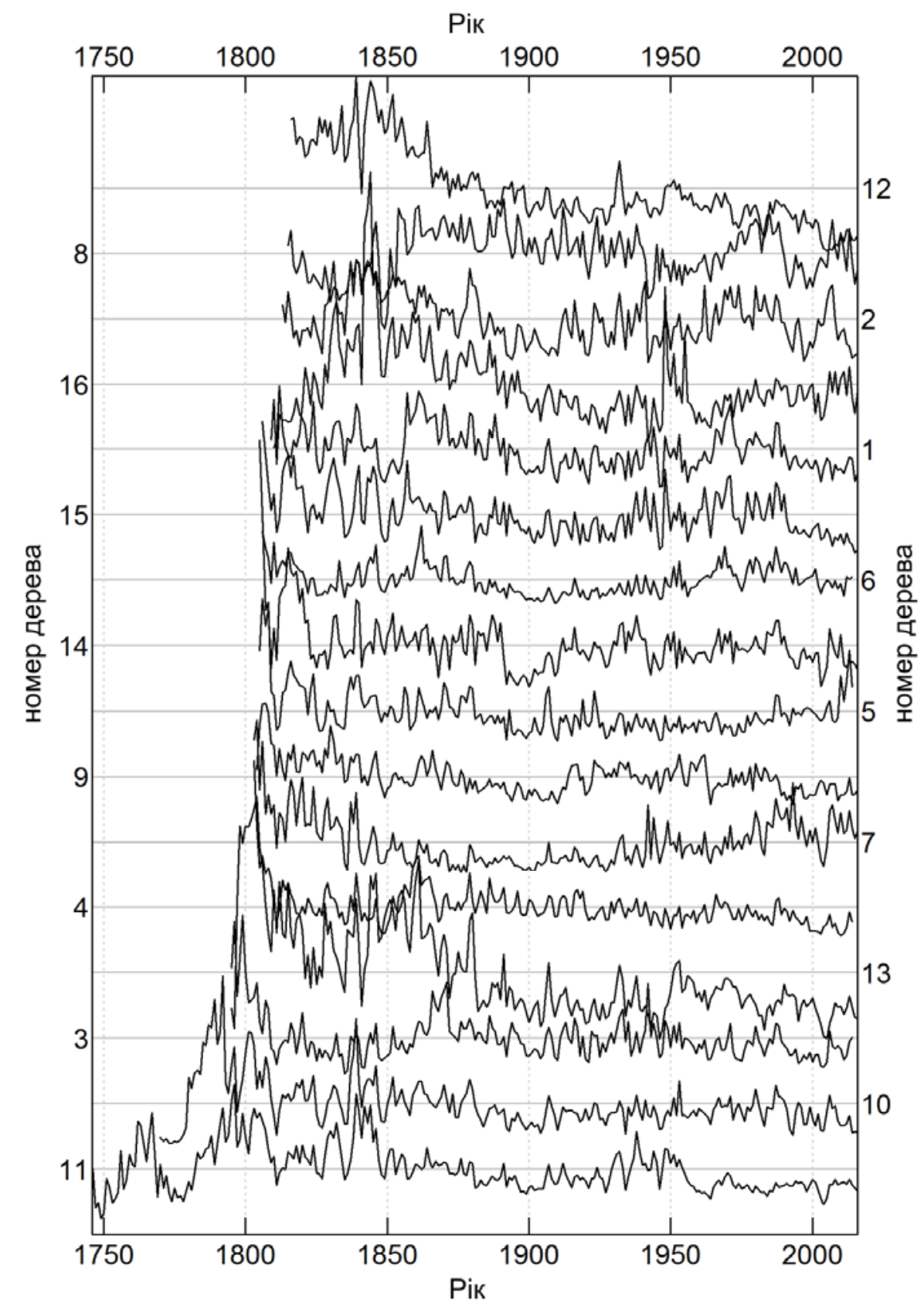

Рис. 1. Індивідуальні хронологічні серії радіального приросту вікових дерев $Q$. robur L.

урочища «Феофанія»

дубів нагірних дібров лісостепу України 3 глибоким заляганням грунтових вод - 0,85 мм (Neshataev et al., 1974).

Через ексцентричність приросту або пошкодженої серцевини лише в дуба № 16 вдалося дістатись ядра, камбіальний вік цього дерева станом на 2016 рік становив 207 років при діаметрі 130,8 см. Найстарішим із досліджених дерев виявився дуб № 11, розрахований камбіальний вік якого становив 275 років при діаметрі 165,2 см (рис. 2.Б), наймолодшим - дуб № 12 віком 202 роки при діаметрі 131,6 см. Довжина хронологічної серії дуба № 6, з найменшим діаметром серед досліджених дерев, становила 209 років, а його оцінений вік 213 років.

За середнім значенням ширини річних кілець досліджених дерев встановлено середній коефіцієнт приросту - 5,13 $\pm 1,428$ років/см (табл. 1), який надає можливість за $1 / 2$ діаметра без кори оцінити вік домінантних та кодомінантних дубів в асоціації Galeobdoloni luteae-Carpinetum Shevchyk, Bakalyna et V.Sl. 1996. Разом з тим варіація локальних біотичних та абіотичних умов зростання, класу дерева за пануванням та життєздатністю зумовлює похибку та обмежує використання коефіцієнтів приросту. Применшення чи перебільшення реального віку старих дубів $є$ поширеним явищем в Україні та за кордоном. Вік дуба «Богатир Тавриди» - пам'ятки природи Криму вважався понад 500 років (Rubtsov, 1959), однак методом порівняльного морфометричного аналізу встановлено, що це дерево не старше 300-350 років (Sevastianov, 2013). Проведені в місті Геттінген дослідження відомого «Дуба Правосуддя» показали, що його вік становить лише близько 300 років, а не 800-1000 років, як вважалось раніше (Sevastianov, 2013). Навпаки, в місті Астрахані зростає дуб, який начебто був посаджений Петром I у 1722 році, але в 2013 році дендрохронологічними методами було 
визначено точний вік дерева - 443 роки (Vserossyiskaia prohramma .., 2013).

Оцінена життєздатність вікових $Q$. robur за 8-бальною шкалою становить переважно 6-7 балів, хоча життєздатність дерева № 13, яке характеризувалось всиханням багатьох скелетних гілок та наявністю чисельних водяних пагонів (табл. 1), відповідала балу 3. Досліджені дерева № 1, 2, 5, 14, 15 - у задовільному санітарному стані, без механічних пошкоджень стовбура, 3 зеленою густою кроною та без зовнішніх ознак всихання. Дерева № 3, 4, 6, 7, 8, 9, 10, 12, 16 були віднесені до категорії «ослаблені», відмічено поранення стовбура, пошкодження листя дубовою міллю Acrocercops brongniardella (Fabricius, 1798) та ураження борошнистою росою Microsphaera alphitoides (Griff. et Maubl., 1910). Дерево № 11 віднесено до III категорії «дуже ослаблені» 3 усиханням скелетних гілок та поїданням листової пластинки міллю понад 50 \%. Дерево № 13 класифікували як «відмираючі», а при аналізі кернів була відмічена центральна гниль.

Стадії рекреаційної дигресії становили від 1 до 4, навколо більшості дерев спостерігалась стадія 1. Оточення навколо дерев № 2, 6, 11, 16 відповідало стадії 2 , що свідчить про пошкодження до $10 \%$ живого надгрунтового покриву, навколо дерев № 1,13 віднесено до стадії 3 пошкоджено до 30 \%, навколо дерев № 12, 15 відповідало стадії 4 з деградуючим трав'яним покривом та підстилкою до $60 \%$ (рис. 2, в).

Кількість багатовікових дерев виду $Q$. robur обмежена, вони зростають у різноманітних умовах природних лісів та насаджень, у тому числі міських, тому заходи 3 догляду та підвищення ї довговічності повинні враховувати індивідуальні особливості дерев та умов. У Швеції було

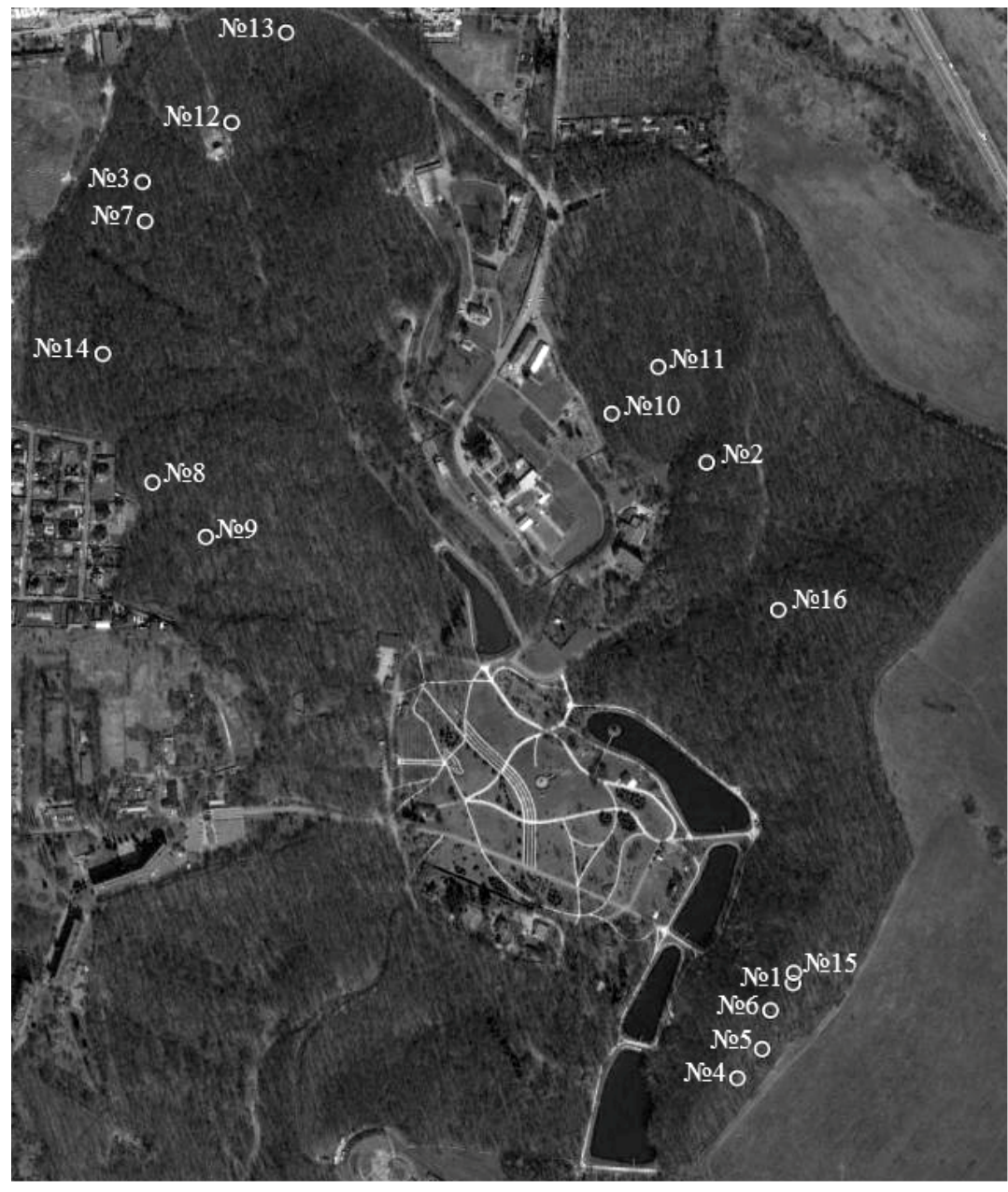

$a$

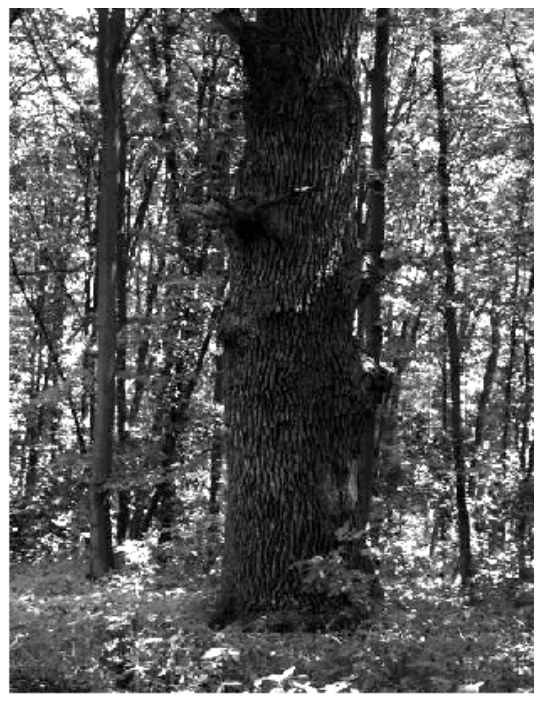

6

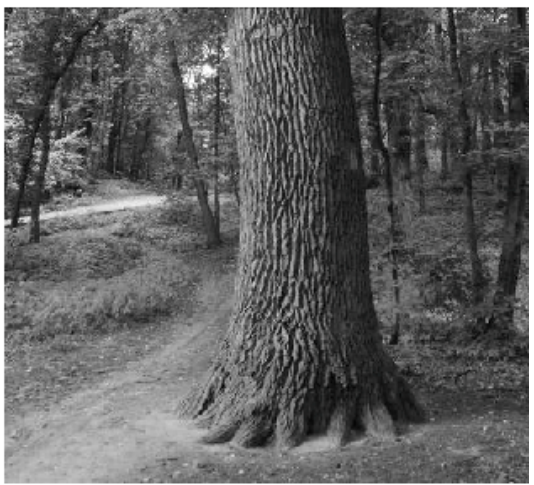

Рис. 2. Схема (Google Earth) розміщення досліджених багатовікових дерев дуба звичайного (a); найстаріше дерево № 11 віком 275 років (б); дерево № 12, що зазнає значного рекреаційного навантаження $(8)$

проведено ряд досліджень щодо грунтових умов, стану кореневої системи, структури стовбура та гілок, здійснено деревно-кільцевий аналіз, оцінку віку та життєздатності одного із найстаріших дерев у Свропі дуба «Kvilleken» - та надано детальні рекомендації щодо покращення його стану (Bengtsson, 2013). В Україні для стабілізації та покращення життєздатності багатовікового історичного дерева «Дуб Максима Залізняка» було запропоновано та проведено ряд заходів - санітарну чистку крони, встановлення системи «COBRA», відновлення живого надгрунтового покриву, зменшення рекреаційного навантаження на кореневу систему (Kushnir et al., 2011).

\section{Висновки}

В урочищі «Феофанія» багатовікові дуби потребують проведення таких санітарно-профілактичних заходів: обрізка сухих та всихаючих гілок у 16 досліджених дерев; для зменшення антропогенного навантаження на кореневу систему, механічних пошкоджень стовбура необхідно встановити огорожі в межах проекції крони для дерев № 1 , 12,1315 , а для зменшення надмірного навантаження на лісовий масив урочища - створити екостежку 3 розміщенням інформаційних стендів по маршруту; рекомендувати надати статус пам'ятки природи деревам № $10,12,13,15$, які зазнають значного рекреаційного навантаження та знаходяться поза межами охоронної 
території парку-пам'ятки садово-паркового мистецтва - на землях, що перебувають у власності КП «ЛПГ«КончаЗаспа» та Свято-Пантелеймонівського монастиря. Виходячи 3 фізіологічних і біомеханічних змін, що відбуваються 3 деревами під час старіння, у майбутньому для досліджених дубів потрібно застосовувати заходи щодо захисту крони від механічних ушкоджень: використовувати підпори, стягуючі обручі для збереження великих скелетних гілок. У разі потреби проводити ліквідацію плодових тіл дереворуйнівних грибів, згрібання листя та плодів, які уражені збудниками хвороб або шкідниками.

\section{References}

Bengtsson, V. (2013). Kvilleken. Assessment and management recommendations. Pro Natura and Hartill Trädexpert AB. $25 \mathrm{p}$.

Bilushenko, A. A. (2015). Vykorystannia rukokrylymy shovyshch $\mathrm{v}$ umovakh Tsentralnogo Lisostepy Ukrainy [Use of the shelters by bats in the Central Forest-Steppe of Ukraine]. Bulletin of Taras Shevchenko National University of Kyiv. Biology Series 2(70), 29-33 (in Ukrainian).

Boreyko, V. E. (2002). Okhrana vekovykh derevyev [Protection of ancient trees]. Naukovyi svit, Kyiv (in Russian).

Drobyshev, I., Niklasson, M. (20100. How old are the largest southern Swedish oaks? A dendrochronological analysis. Ecological Bulletins, 53, 155-163.

Drobyshev, I., Niklasson, M., Linderson, H., Sonneson, K., Karlsson, M., Nilsson, S. G., Lanner, J. (2008). Lifespan and mortality of old oaks - combining empirical and modelling approaches to support their management in Southern Sweden. Annals of Forest Science, 65, 1-12.

Halkin, S. I., Drahan N. V., Doiko N. M. (2013). Dosvid zberezhennia vikovykh derev ta istorychnykh nasadzhen $\mathrm{u}$ dendrolohichnomu parku «Oleksandriia» NAN Ukrainy [Experience the conservation of ancient trees and historical compositions in arboretum Olexandria of the NAS of Ukraine]. Plant introduction, 4, 42-50 (in Ukrainian).

Hensiruk, S. A., Nizhnik, M. S., Voznyak, R. R. (1987). Rekreatsionnoye ispolzovaniye lesov [Recreational forest management]. Urozhai, Kyiv (in Russian).

Holmes, R. L. (1983). Computer-assisted quality control in treering dating and measurement. Tree-Ring Bulletin, 43, 69-78.

Hrynyk, P. I., Stetsenko, M. P., Shnaider, L. S., Lystopad, O. H., Boreiko, V. E. (2010). Starodavni dereva Ukrainy. Reiestrdovidnyk [Ancient trees of Ukraine. Inventory handbook]. Logos, Kyiv (in Ukrainian).

Klymenko, Yu. O., Kuznietsov, S. I., Cherniak, V. M. (1996). Starovynni parky Ukrainy zahalnoderzhavnoho znachennia: Dovidnyk. Ch. 1. Polissia ta Lisostep [Old parks with National significance of Ukraine. Part 1. Polesie and Forest-Steppe]. Mandrivets, Ternopil (in Ukrainian).

Kushnir, A. I., Hryzherchyk, V., Sukhanova, O. A. (2011). Novitni tekhnolohii zberezhennia vikovykh derev $\mathrm{u}$ Yevropi [The newest technologies of maintainance of trees-veterans in Europe]. Scientific Bulletin of UNFU, 21.16, 240-245 (in Ukrainian).

Lisovyi kodeks Ukrainy [Forestry Code of Ukraine]. Access mode: http://zakon2.rada.gov.ua/laws/show/3852-12/page2.

Lypa, A. L. (1958). Mnogovekovyye derevia tissa v Krymu [Old-growth yew trees in Crimea]. Bulletin of Botanical Garden, 31 (in Russian).
Lypa, A. L. (1967). Dostoprimechatelnyye derevia Kryma [Remarkable trees of Crimea]. Crimea, Simferopol (in Russian).

Matiashuk, R. K., Nebesnyi, V. B., Koniakin, S. M., Tkachenko, I. V., Prokopuk, Yu. S. (2014). Vikovi duby «Feofanii» - pamiatky zhyvoi pryrody krayu [Senturies-old «Feofaniya» oaks - region wildlife monuments]. Scientific reports of National University of Life and Environmental sciences of Ukraine 6. Access mode: http://nbuv.gov.ua/UJRN/Nd_2014_6_18 (in Ukrainian).

Neshataev, Yu. N., Plavnikov, V. G., Samilyak, S. I., Schastnaya, L. S., Tereshenkova, I. A. (1974). Lesostepnaya dubrava «Les na Vorskle» [Forest-steppe oak forest «Forest on the Vorskla river»]. Scientific notes of Leningrad university, 53(367), 7-40 (in Russian).

Netsvetov, M. V., Prokopuk, Yu. S. (2016). Vik i radialnyi pryrist starovikovykh derev Quercus robur parku «Feofaniia» [Age and radial growth of age-old trees of Quercus robur in Feofania Park]. Ukrainian Botanical Journal, 73(2), 126-133 (in Ukrainian).

Netsvetov, M., Sergeyev, M., Nikulina, V., Korniyenko, V., Prokopuk, Yu. (2017). The climate to growth relationships of pedunculate oak in steppe. Dendrochronologia, 44, 31-38.

Oleksiichenko, N. O., Podolkhova, M. O. (2016). Vikovi dereva dendroparkiv Ukrainskoho Polissia [Age-old trees of Ukrainian Polissya's Dendrological Parks]. Scientific Bulletin of UNFU, 26.4, 22-27 (in Ukrainian).

Onyshchenko, V. A. (2015). Vikovi duby Holosiivskoho lisu [Old oaks of Holosiyivsky wood]. Nature conservation, 1(21), 19-24 (in Ukrainian).

Popovych, S. Yu. (2011). Dendrosozolohichnyi kataloh pryrodno-zapovidnoho fondu Lisostepu Ukrainy [Dendrosozological list of Forest-Steppe natural-reserved fund of Ukraine]. Ahar Media Grup, Kyiv (in Ukrainian).

Rozas, V. (2003). Tree age estimates in Fagus sylvatica and Quercus robur: testing previous and improved methods. Plant Ecology, 167, 193-212.

Rubtsov, L. I. (1959). Dostoprimechatelnyye ekzemplyary duba v Krymu [Remarkable oak trees in Crimea]. Bulletin of Botanical Garden, 35, 117-119 (in Russian).

Sanitarni pravyla v lisakh Ukrainy (1995) [Sanitary Regulations in forests of Ukraine]. Kyiv (in Ukrainian).

Saveleva, L. S. (1975). Ustoychivost derevyev i kustarnikov v zashchitnykh lesnykh nasazhdeniyakh [Stability of trees and shrubs in protective forest stands]. Lesnaya promyshlennost, Moscow (in Russian).

Sevastianov, V. E. (2013). Ispolzovaniye sravnitelnogo morfometricheskogo analiza pri opredelenii vozrasta nekotorykh dostoprimechatelnykh derevyev duba v Krymu [The use of comparative morphometric analysis in the age determination of some remarkable oak trees in Crimea]. Materials of international scientific conference. KyivChyhyryn, 31-32 (in Russian).

Shnayder, S. L. Boreyko, V. E., Stetsenko, N. F. (2011). 500 vydayushchikhsya derevyev Ukrainy [500 exceptional trees of Ukraine]. Lotos, Kyiv (in Russian).

Vserossiyskaya programma «Derevia - pamyatniki zhivoy prirody» (2010). [Russian program «Trees - Nature Monuments»]. Access mode: http://rosdrevo.ru/index.php?option=com adsmanager\&page $=$ show_ad\&adid $=37 \&$ catid $=1 \&$ Itemid $=85$ (in Russian).

White, J. (1998). Estimating the age of large and veteran trees in Britain Forest. Information Note, 250, UK Forestry Commission. 